\title{
Intensive care unit surveillance of influenza infection in France: the 2009/10 pandemic and the three subsequent
}

\section{seasons}

\author{
I Bonmarin ${ }^{1}$, E Belchior ${ }^{1}$, J Bergounioux ${ }^{2}$, C Brun-Buisson ${ }^{3}$, B Mégarbane ${ }^{4}$, JL Chappert ${ }^{5}$, B Hubert ${ }^{5}$, Y Le Strat ${ }^{1}$, D Lévy- \\ Bruhl ${ }^{1}$ \\ 1. Institut de Veille sanitaire (InVS), Saint-Maurice, France \\ 2. Paediatric Intensive Care Unit, Raymond Poincaré Hospital, Garches, France \\ 3. Intensive Care Unit, CHU Henri-Mondor, Créteil, France \\ 4. Intensive care unit and toxicological department, Lariboisière Hospital, Paris-Diderot University, INSERM, Paris, France \\ 5. On behalf of the Cellules de l'InVS en région (Cire), the InVS regional offices, France
}

Correspondence: Isabelle Bonmarin (i.bonmarin@invs.sante.fr)

Citation style for this article:

Bonmarin I, Belchior E, Bergounioux J, Brun-Buisson C, Mégarbane B, Chappert J, Hubert B, Le Strat Y, Lévy-Bruhl D. Intensive care unit surveillance of influenza infection in France: the 2009/10 pandemic and the three subsequent seasons. Euro Surveill. 2015;20(46):pii=30066. DOI: http://dx.doi.org/10.2807/1560-7917. ES.2015.20.46.30066

Article submitted on 13 November 2014 / accepted on 30 March 2015 / published on 19 November 2015

During the 2009/10 pandemic, a national surveillance system for severe influenza cases was set up in France. We present results from the system's first four years. All severe influenza cases admitted to intensive care units (ICU) were reported to the Institut de Veille Sanitaire using a standardised form: data on demographics, immunisation and virological status, risk factors, severity (e.g. acute respiratory distress syndrome (ARDS) onset, mechanical ventilation, extracorporeal life support) and outcome. Multivariate analysis was performed to identify factors associated with ARDS and death. The number of confirmed influenza cases varied from 1,210 in 2009/10 to 321 in $2011 / 12$. Most ICU patients were infected with $A\left(H_{1} N_{1}\right)$ pdmo9, except during the 2011/12 winter season when $A\left(\mathrm{H}_{3} \mathrm{~N}_{2}\right)$-related infections predominated. Patients' characteristics varied according to the predominant strain. Based on multivariate analysis, risk factors associated with death were age $\geq 65$ years, patients with any of the usual recommended indications for vaccination and clinical severity. ARDS occurred more frequently in patients who were middle-aged (36-55 years), pregnant, obese, or infected with $A\left(\mathrm{H}_{1} \mathrm{~N}_{1}\right)$ pdmo9. Female sex and influenza vaccination were protective. These data confirm the persistent virulence of $\mathrm{A}\left(\mathrm{H}_{1} \mathrm{~N}_{1}\right)$ pdmog after the pandemic and the heterogeneity of influenza seasons, and reinforce the need for surveillance of severe influenza cases.

\section{Introduction}

Historically, the epidemiological surveillance of influenza in France has mainly been carried out in general practice, through two networks: the Réseau des Grog [1] and Sentinelles [2]. The Réseau des Grog also collected nasopharyngeal specimens for virological surveillance. During the 2009/10 pandemic, those two networks uploaded their data to the same database and for the first time, used a common case definition (sudden onset of fever $\left(>39^{\circ} \mathrm{C}\right)$ with myalgia and respiratory signs). An intensive care unit (ICU) surveillance system was created to monitor severe cases of influenza [3]. Clinicians were asked to report all influenza cases admitted to ICUs to the French Institute for Public Health Surveillance (Institut de veille sanitaireInVS). Both biologically confirmed and probable (based on clinician clinical judgement) influenza cases had to be notified. Biological confirmation relied on a positive influenza reverse transcriptase-PCR (RT-PCR) performed on a respiratory sample. This ICU surveillance was maintained after the pandemic season. Data collected were restricted to a one-page standardised notification form which was forwarded to the InVS regional offices (Cire). In order to reach a high level of notification, each of the 17 Cires regularly contact the ICUs in their own region to ensure that all influenza cases are reported, to complete the missing information and to follow patients' evolution until ICU discharge or death. They also regularly matched the ICUs surveillance data with the hospital virological database. The adult and paediatric French Societies of Anaesthesia and Critical Care Medicine provided strong support for this surveillance.

The surveillance system was exhaustive except in December 2010: the surveillance started with an ICU sentinel network in week 50 in 2010 and was extended to all ICUs in week 01 in 2011 due to the worryingly high number of influenza-based ICU admissions reported in the United Kingdom [4]. 
Weekly number of severe influenza admissions to intensive care and weekly general physician consultation incidence rate, France, week 28/2009 to week 17/2012

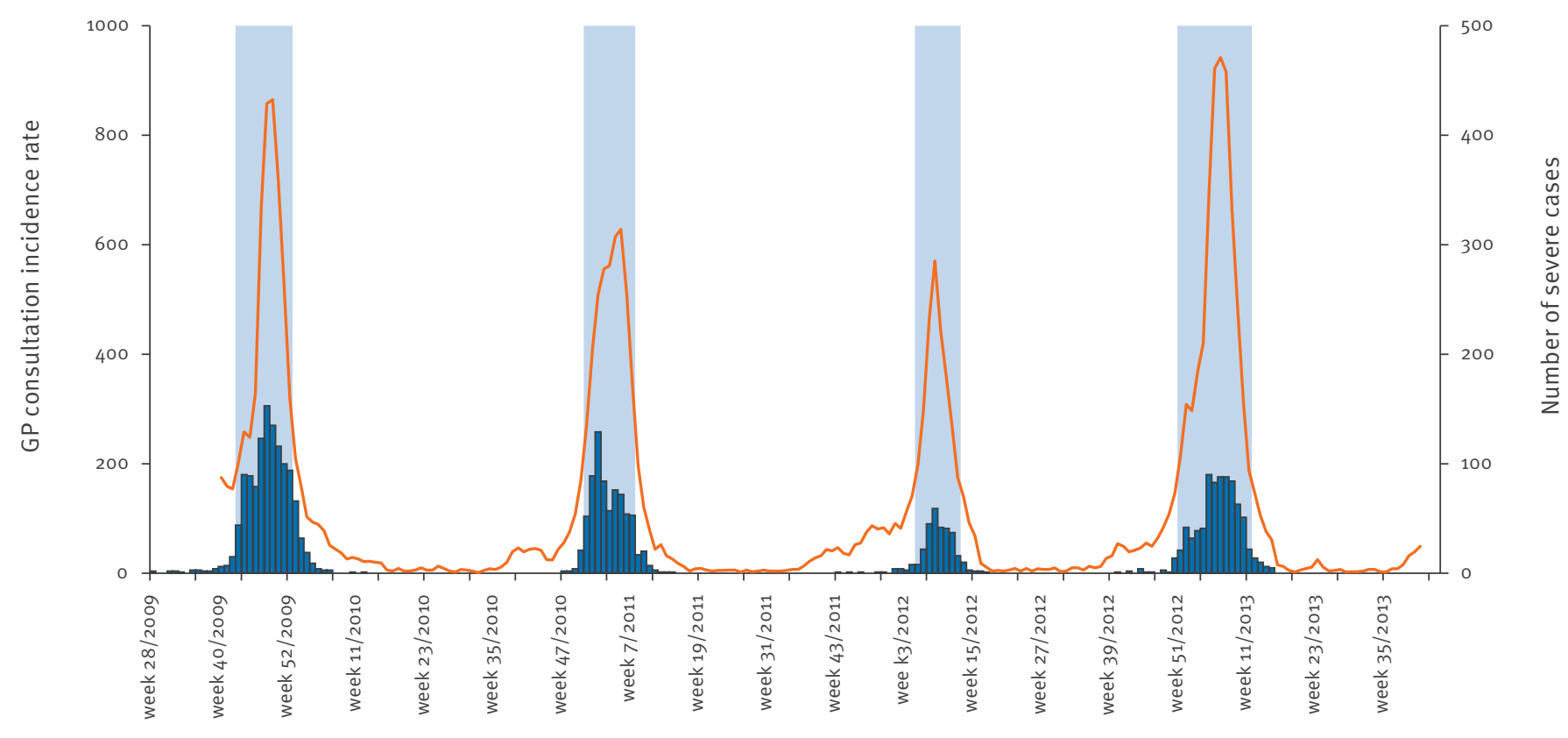

Week

$\mathrm{A}\left(\mathrm{H}_{1} \mathrm{~N}_{1}\right)$-associated ICU admissions data during the pandemic and the following season have been described extensively [3,5-7]. However, little has been published on the characteristics of severe influenza cases hospitalised in ICU during seasonal influenza. We used the first four years of ICU surveillance to describe and compare patient characteristics according to the season and the influenza virus circulating, and we looked at the risk factors associated with death and acute respiratory distress syndrome (ARDS).

\section{Methods}

This study included only laboratory-confirmed influenza cases admitted to ICU in mainland France that were reported during the pandemic (2009/10) and the subsequent three winter seasons. The data collected were as follows: demographics (age, sex, region); date of ICU admission; up to three non-exclusive risk factors for severe influenza as follows: (i) obesity (defined by body mass index (body mass index $(B M I) \geq 30 \mathrm{~kg} / \mathrm{m}^{2}$ ), (ii) pregnancy and (iii) belonging to the vaccine-targeted group according to recommendations (patients with chronic disease [8] or over 65 years old); influenza vaccination status (except during the pandemic); viral type and subtype; severity (ARDS presentation, need for mechanical ventilation or extracorporeal membrane oxygenation (ECMO)); and outcome (discharge or death). All dichotomous variables were formatted as a yes/no answer, except for ECMO and mechanic ventilation where only affirmative answers were collected.
With the exception of the pandemic year, when surveillance started in July, seasonal influenza surveillance usually ran from mid-November or the beginning of December until April. Surveillance was exhaustive, except in December 2010 when the severe case surveillance started with an ICU sentinel network in most regions. To take into account these three weeks of sentinel surveillance in all regions, the number of cases reported during these three weeks $\left(\mathrm{N}_{\text {Sent_o }}\right)$ in each region was divided by the proportion of cases notified by the ICU sentinel hospitals in this region after surveillance extension $\left(\mathrm{N}_{\mathrm{Sent}_{-1}} /\left[\mathrm{N}_{\text {Sent }_{1} 1}+\mathrm{N}_{\mathrm{NonSent}_{1} 1}\right]\right)$. For that season, the number of admissions by age was estimated by applying the age distribution of observed cases to the extrapolated number of admissions.

Weekly ICU admission rates were compared with weekly estimated incidence of influenza-like illness (ILI) consultations, obtained from the general practitioners (GP) surveillance network. In the present study, we also compared the virus distribution among ICU patients and GP patients. Average population figures from 2009 to 2012, provided by the Institut national de la statistique et des études économiques (Insee), were used to calculate the French population age distribution. The age-specific admission rates for each season were calculated using yearly population data, starting with 2009 figures for the $2009 / 10$ season. 


\section{FIGURE 2}

Age-admission rate (A) and age-admission distribution (B) of severe influenza cases in intensive care units, compared with age-distribution in the general population, France, influenza seasons 2009/10 to 2012/13

A. Age-admission rate

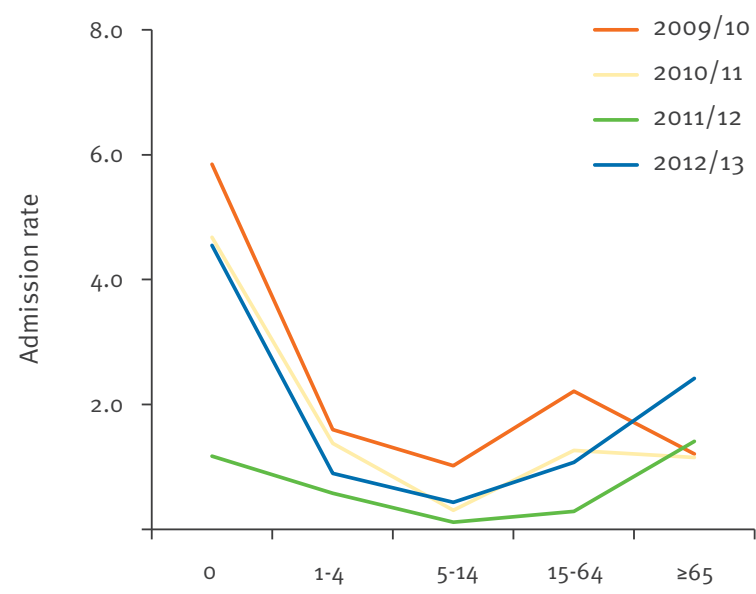

Age group (years old)

B. Age-admission distribution

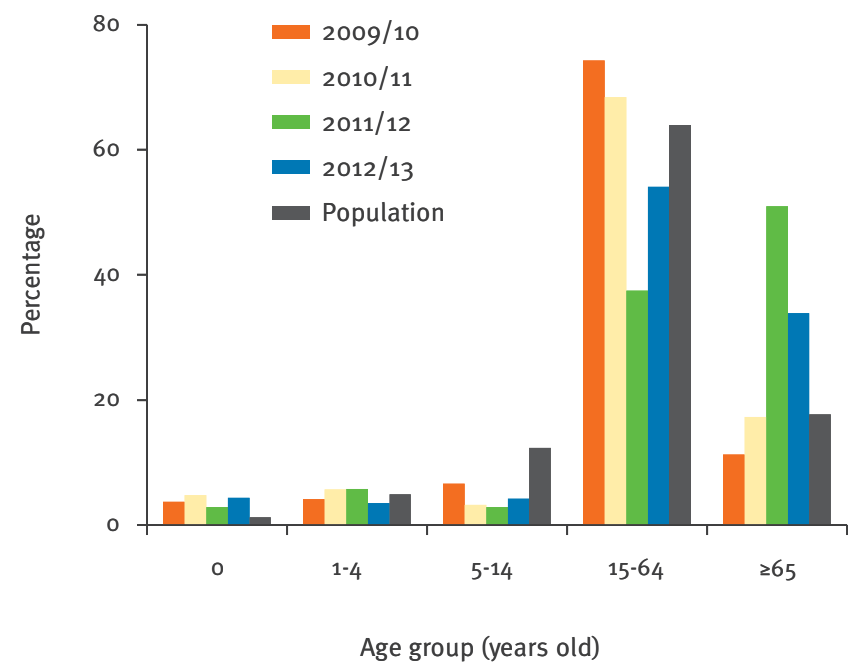

Influenza epidemic periods were those defined by Sentinelles: this GP network used an epidemic threshold based on a periodic regression model [9].

The percentage of missing data for different variables and seasons ranged from $1 \%$ to $32 \%$ (Table 1 ). In order to reduce potential bias arising from complete-case analysis and because the missing at random (MAR) assumption was plausible for the incomplete variables, we performed multiple imputations by chained equations to deal with missing values (non-subtyped $A$ virus treated as missing data). Stataıs user-written programme ice was used. We created 100 complete datasets. Except for the admission date, all the variables were included in the imputation procedures, as were all the possible interactions.
A descriptive study was first undertaken using multiple imputation analysis. Two multivariate logistic regressions were performed to identify factors associated with death and ARDS. All independent variables, including age, were defined as categorical. Including age as a continuous variable required techniques (fractional polynomials, splines), difficult to use with multiple imputation data. Age groups were defined as follows: $0-35$ years, $36-55$ years, and $>56$ years. Obesity or pregnancy with no other risk factor were differentiated from the risk factors defined above. We set up three levels of disease severity: no ARDS (score o), ARDS not requiring ECMO (score 1) and ARDS requiring ECMO (score 2). With the exception of the date of admission, all variables were considered eligible for the model and were tested using logistic regression. For each non-dichotomous variable with several categories, the reference chosen was the category with the closest proportion to the proportion of death (or ARDS) among ICU cases as a whole. A variable was considered to be associated with death (or ARDS) in the multivariate analysis if the $p$ value was $\leq 0.05$. As data on vaccination status were not properly collected in 2009/10, we tested its association with death (or ARDS) in a multivariate analysis for the post-pandemic period. If vaccination was associated with death (or ARDS), we kept the variable, excluding the 2009/10 data. If not, we removed it from the final model and performed an analysis on the whole period, including 2009/10.

The analysis was performed using Stata 12. For the descriptive and multivariate analysis, the results based on multiple imputations were compared with results restricted to complete cases.

\section{Results}

Throughout the four seasons, 3,074 confirmed cases were notified, representing $95 \%$ of all probable and confirmed notified cases. The epidemic period began in the weeks starting 12 October 2009, 20 December 2010, 30 January 2012 and 17 December 2012 and lasted 10, 9, 8, and 13 weeks respectively. The first severe influenza cases to be reported were admitted 14 weeks before the onset of the pandemic wave, and 4,14 and 11 weeks before the epidemic threshold was reached during the subsequent seasons. The epidemic curve of the weekly admissions to ICU was almost parallel to the weekly influenza-like illness GP consultation rate curve (Figure 1).

During the surveillance period, the number of reported cases decreased dramatically from 1,210 during the pandemic to 312 in 2011/12. During the epidemic periods, around $90 \%$ of the cases were admitted and the same trend was observed with a number of admissions varying from 1,038 during the pandemic to 270 in 2011/12. If the surveillance system had been exhaustive in December 2010, the number of cases would have been 793 during the 2010/11 season. 
TABLE 1

Characteristics of influenza cases admitted to intensive care units by influenza season, France, influenza seasons 2009/10-2012/13

\begin{tabular}{|c|c|c|c|c|c|c|c|c|c|c|c|c|}
\hline \multirow[b]{2}{*}{ ICU cases } & \multicolumn{3}{|c|}{$2009 / 10$} & \multicolumn{3}{|c|}{$2010 / 11$} & \multicolumn{3}{|c|}{$2011 / 12$} & \multicolumn{3}{|c|}{$2012 / 13$} \\
\hline & $\begin{array}{l}\text { Missing } \\
\text { data }\end{array}$ & $\mathrm{CC}$ & $\begin{array}{c}\text { Multiple } \\
\text { imputation } \\
(95 \% \mathrm{CI})\end{array}$ & $\begin{array}{l}\text { Missing } \\
\text { data }\end{array}$ & $\mathrm{CC}$ & $\begin{array}{c}\text { Multiple } \\
\text { imputation } \\
(95 \% \mathrm{CI})\end{array}$ & $\begin{array}{c}\text { Missing } \\
\text { data }\end{array}$ & $\mathrm{CC}$ & $\begin{array}{l}\text { Multiple } \\
\text { imputation } \\
(95 \% \mathrm{Cl})\end{array}$ & $\begin{array}{l}\text { Missing } \\
\text { data }\end{array}$ & CC & \begin{tabular}{|c} 
Multiple \\
imputation \\
$(95 \% \mathrm{CI})$
\end{tabular} \\
\hline \multicolumn{13}{|l|}{ Age and sex } \\
\hline Mean age (years) & ०\% & 40.9 & $\begin{array}{c}40.9 \\
(39.7-42.1)\end{array}$ & $1 \%$ & 44.6 & $\begin{array}{c}44.6 \\
(42.9-46.2)\end{array}$ & $0 \%$ & 58.5 & $\begin{array}{c}58.5 \\
(55.8-61.3) \\
\end{array}$ & $0 \%$ & 52.7 & $\begin{array}{c}52.7 \\
(51.0-54.3)\end{array}$ \\
\hline Male & $0 \%$ & $53 \%$ & $53 \%(50-56)$ & $1 \%$ & $58 \%$ & $\begin{array}{c}58 \% \\
(54-61) \\
\end{array}$ & $0 \%$ & $55 \%$ & $\begin{array}{c}55 \% \\
(49-60) \\
\end{array}$ & $0 \%$ & $54 \%$ & $\begin{array}{c}54 \% \\
(51-58)\end{array}$ \\
\hline Risk factors & $1 \%$ & & & $2 \%$ & & & $1 \%$ & & & $1 \%$ & & \\
\hline None & - & $27 \%$ & $\begin{array}{c}27 \% \\
(24-29)\end{array}$ & - & $35 \%$ & $\begin{array}{c}35 \% \\
(32-39)\end{array}$ & - & $18 \%$ & $\begin{array}{c}18 \% \\
(14-23)\end{array}$ & - & $22 \%$ & $\begin{array}{c}22 \% \\
(19-25)\end{array}$ \\
\hline $\begin{array}{l}\text { Chronic disease } \\
\text { and age } \geq 65\end{array}$ & - & $63 \%$ & $\begin{array}{c}63 \% \\
(60-66) \\
\end{array}$ & - & $50 \%$ & $\begin{array}{c}50 \% \\
(46-53)\end{array}$ & - & $80 \%$ & $\begin{array}{c}80 \% \\
(76-85)\end{array}$ & - & $72 \%$ & $\begin{array}{c}72 \% \\
(69-75)\end{array}$ \\
\hline $\begin{array}{l}\text { Pregnancy with no } \\
\text { other risk factor }\end{array}$ & - & $3 \%$ & $3 \%(2-4)$ & - & $4 \%$ & $4 \%(3-5)$ & - & $1 \%$ & $1 \%(0-2)$ & - & $1 \%$ & $\begin{array}{c}1 \% \\
(0-2)\end{array}$ \\
\hline $\begin{array}{l}\text { Obesity with no } \\
\text { associated risk } \\
\text { factor }\end{array}$ & - & $7 \%$ & $7 \%(6-9)$ & - & $11 \%$ & $\begin{array}{c}11 \% \\
(9-13)\end{array}$ & - & $1 \%$ & $1 \%(0-2)$ & - & $5 \%$ & $\begin{array}{l}5 \% \\
(3-6)\end{array}$ \\
\hline Pregnancy a & - & $5 \%$ & $5 \%(4-6)$ & - & $4 \%$ & $\begin{array}{c}4 \% \\
(3-5)\end{array}$ & - & $1 \%$ & $1 \%(0-2)$ & - & $2 \%$ & $\begin{array}{c}2 \% \\
(0-2)\end{array}$ \\
\hline $\begin{array}{l}\text { Obesity>17 years- } \\
\text { old }^{a}\end{array}$ & - & $20 \%$ & $20 \%(17-22)$ & - & $23 \%$ & $\begin{array}{c}23 \% \\
(20-26)\end{array}$ & - & $16 \%$ & $\begin{array}{c}16 \% \\
(11-20)\end{array}$ & - & $15 \%$ & $\begin{array}{c}15 \% \\
(12-18)\end{array}$ \\
\hline \multicolumn{13}{|l|}{ Seasonal vaccination } \\
\hline Vaccinated ${ }^{\mathrm{b}}$ & - & - & - & $31 \%$ & $\begin{array}{c}12 \% \\
(n=63)\end{array}$ & $\begin{array}{c}13 \% \\
(10-16)\end{array}$ & $25 \%$ & $\begin{array}{c}28 \% \\
(n=66)\end{array}$ & $\begin{array}{c}29 \% \\
(23-34)\end{array}$ & $31 \%$ & $\begin{array}{c}16 \% \\
(n=89)\end{array}$ & $\begin{array}{c}16 \% \\
(13-19)\end{array}$ \\
\hline \multicolumn{13}{|l|}{ Influenza severity } \\
\hline ARDS & $0 \%$ & $46 \%$ & $46 \%(43-49)$ & $1 \%$ & $64 \%$ & $\begin{array}{c}64 \% \\
(60-67) \\
\end{array}$ & $0 \%$ & $43 \%$ & $\begin{array}{c}43 \% \\
(37-48) \\
\end{array}$ & $0 \%$ & $50 \%$ & $\begin{array}{c}50 \% \\
(46-53) \\
\end{array}$ \\
\hline ECMO & - & $7 \%$ & $7 \%(6-8)$ & - & $10 \%$ & $\begin{array}{c}10 \% \\
(8-12) \\
\end{array}$ & NA & $3 \%$ & $3 \%(1-5)$ & - & $7 \%$ & $\begin{array}{c}7 \% \\
(5-8) \\
\end{array}$ \\
\hline $\begin{array}{l}\text { Mechanical } \\
\text { ventilation }\end{array}$ & $22 \%$ & $59 \%$ & $59 \%(56-62)$ & - & $66 \%$ & $\begin{array}{c}66 \% \\
(62-69)\end{array}$ & NA & $62 \%$ & $\begin{array}{c}62 \% \\
(56-67)\end{array}$ & - & $64 \%$ & $\begin{array}{c}64 \% \\
(61-68)\end{array}$ \\
\hline Death ${ }^{\mathrm{b}}$ & $32 \%$ & $\begin{array}{c}27 \% \\
(n=221)\end{array}$ & $18 \%(16-20)$ & $0 \%$ & $\begin{array}{c}20 \% \\
(n=148)\end{array}$ & $\begin{array}{c}20 \% \\
(17-23)\end{array}$ & $1 \%$ & $\begin{array}{c}16 \% \\
(n=49)\end{array}$ & $\begin{array}{c}16 \% \\
(12-20)\end{array}$ & $1 \%$ & $\begin{array}{c}19 \% \\
(n=152)\end{array}$ & $\begin{array}{c}19 \% \\
(16-22)\end{array}$ \\
\hline \multicolumn{13}{|l|}{ Severity score } \\
\hline Score o: No ARDS & - & $54 \%$ & $54 \%(51-57)$ & - & $36 \%$ & $\begin{array}{c}36 \% \\
(33-40) \\
\end{array}$ & - & $57 \%$ & $\begin{array}{c}57 \% \\
(52-63)\end{array}$ & - & $51 \%$ & $\begin{array}{c}50 \% \\
(47-54) \\
\end{array}$ \\
\hline $\begin{array}{l}\text { Score 1: ARDS with } \\
\text { no ECMO }\end{array}$ & - & $39 \%$ & $39 \%(37-42)$ & - & $54 \%$ & $\begin{array}{c}54 \% \\
(51-58) \\
\end{array}$ & - & $40 \%$ & $\begin{array}{c}40 \% \\
(35-46) \\
\end{array}$ & - & $43 \%$ & $\begin{array}{c}43 \% \\
(40-46) \\
\end{array}$ \\
\hline $\begin{array}{l}\text { Score 2: ARDS } \\
\text { with ECMO }\end{array}$ & - & $7 \%$ & $7 \%(6-8)$ & - & $10 \%$ & $\begin{array}{c}10 \% \\
(8-12)\end{array}$ & - & $3 \%$ & $3 \%(1-5)$ & - & $7 \%$ & $\begin{array}{c}6 \% \\
(5-8)\end{array}$ \\
\hline \multicolumn{13}{|l|}{ Laboratory results } \\
\hline $\mathrm{A}\left(\mathrm{H}_{1} \mathrm{~N}_{1}\right) \mathrm{pdmog}$ & - & $94 \%$ & $100 \%$ & - & $60 \%$ & $\begin{array}{c}85 \% \\
(83-88) \\
\end{array}$ & - & $6 \%$ & $\begin{array}{c}15 \% \\
(9-21) \\
\end{array}$ & - & $25 \%$ & $\begin{array}{c}46 \% \\
(42-51)\end{array}$ \\
\hline $\mathrm{A}\left(\mathrm{H}_{3} \mathrm{~N}_{2}\right)$ & - & ०\% & - & - & $2 \%$ & $\begin{array}{c}3 \% \\
(2-5)\end{array}$ & - & $39 \%$ & $\begin{array}{c}83 \% \\
(77-89)\end{array}$ & - & $12 \%$ & $\begin{array}{c}23 \% \\
(19-27)\end{array}$ \\
\hline Non-subtyped A & - & $6 \%$ & - & - & $27 \%$ & - & - & $53 \%$ & - & - & $32 \%$ & - \\
\hline B & - & ०\% & - & - & $11 \%$ & $\begin{array}{c}11 \% \\
(9-14)\end{array}$ & - & $2 \%$ & $2 \%(0-3)$ & - & $31 \%$ & $\begin{array}{c}31 \% \\
(28-34) \\
\end{array}$ \\
\hline Total observations & - & 1,210 & - & - & 746 & - & - & 312 & - & - & 806 & - \\
\hline \multicolumn{13}{|c|}{ Virus testing at GP practices } \\
\hline $\mathrm{A}\left(\mathrm{H}_{1} \mathrm{~N}_{1}\right) \mathrm{pdmog}$ & - & $95 \%$ & - & - & $40 \%$ & - & - & $4 \%$ & - & - & $21 \%$ & - \\
\hline $\mathrm{A}\left(\mathrm{H}_{3} \mathrm{~N}_{2}\right)$ & - & $0 \%$ & - & - & $6 \%$ & - & - & $86 \%$ & - & - & $18 \%$ & - \\
\hline Non sub-typed A & - & $5 \%$ & - & - & $8 \%$ & - & - & $5 \%$ & - & - & $6 \%$ & - \\
\hline B & - & $0 \%$ & - & - & $46 \%$ & - & - & $5 \%$ & - & - & $55 \%$ & - \\
\hline
\end{tabular}

ARDS: acute respiratory distress syndrome; $\mathrm{CC}$ : complete case; $\mathrm{Cl}$ : confidence interval; $\mathrm{ECMO}$ : extracorporeal membrane oxygenation; GP: general practitioner; ICU: intensive care unit; -: not applicable.

Virus distribution generated through general practitioner-based sentinel surveillance.

a With or without associated risk factor

${ }^{b}$ Numerator in bracket 
Bivariate analysis of death and multivariate analysis to identify risk factors associated with death in influenza patients, France, influenza seasons 2009/10-2012/13

\begin{tabular}{|c|c|c|c|c|c|c|c|c|}
\hline & \multicolumn{2}{|c|}{ Univariate analysis } & \multicolumn{6}{|c|}{ Multivariate analysis } \\
\hline & \multirow[t]{2}{*}{ Complete cases } & \multirow{2}{*}{$\begin{array}{l}\text { Multiple imputation } \\
(95 \% \mathrm{Cl})\end{array}$} & \multicolumn{3}{|c|}{ Complete cases $(n=2,041)$} & \multicolumn{3}{|c|}{$\begin{array}{l}\text { Multiple imputation } \\
(n=3,034)\end{array}$} \\
\hline & & & OR & \multicolumn{2}{|c|}{$95 \% \mathrm{Cl}$} & OR & \multicolumn{2}{|c|}{$95 \% \mathrm{Cl}$} \\
\hline \multicolumn{9}{|l|}{ Age } \\
\hline $0-35$ years & $13 \%$ & $11 \%(9-13)$ & 0.7 & 0.5 & 1.0 & 0.7 & 0.5 & 0.9 \\
\hline $36-55$ years & $22 \%$ & $18 \%(16-21)$ & \multicolumn{3}{|c|}{ Ref } & \multicolumn{3}{|c|}{ Ref } \\
\hline$>55$ years & $26 \%$ & $24 \%(22-26)$ & 1.2 & 0.9 & 1.6 & 1.5 & 1.2 & 1.9 \\
\hline \multicolumn{9}{|l|}{ Sex } \\
\hline Male & $22 \%$ & $19 \%(17-21)$ & \multirow{2}{*}{\multicolumn{6}{|c|}{ Not included }} \\
\hline Female & $21 \%$ & $18 \%(19-20)$ & & & & & & \\
\hline \multicolumn{9}{|l|}{ Risk factors } \\
\hline None & $14 \%$ & $12 \%(10-14)$ & 0.4 & 0.3 & 0.6 & 0.5 & 0.4 & 0.6 \\
\hline Chronic disease and age $\geq 65$ years & $25 \%$ & $22 \%(20-24)$ & \multicolumn{3}{|c|}{ Ref } & \multicolumn{3}{|c|}{ Ref } \\
\hline Pregnancy with no other risk factor & $13 \%$ & $11 \%(4-18)$ & 0.3 & 0.1 & 0.6 & 0.3 & 0.1 & 0.7 \\
\hline Obesity with no other risk factor & $18 \%$ & $15 \%(10-20)$ & 0.4 & 0.2 & 0.6 & 0.4 & 0.3 & 0.6 \\
\hline \multicolumn{9}{|c|}{ Seasonal vaccination (2009/10 excluded) } \\
\hline No & $17 \%$ & $19 \%(17-21)$ & \multirow{2}{*}{\multicolumn{6}{|c|}{ Not included }} \\
\hline Yes & $17 \%$ & $19 \%(13-24)$ & & & & & & \\
\hline \multicolumn{9}{|l|}{ Severity } \\
\hline Score o: No ARDS & $10 \%$ & $8 \%(7-10)$ & \multicolumn{3}{|c|}{ Ref } & \multicolumn{3}{|c|}{ Ref } \\
\hline Score 1: ARDS with no ECMO & $30 \%$ & $27 \%(25-29)$ & 4.0 & 3.0 & 5.2 & 4.2 & 3.3 & 5.3 \\
\hline Score 2: ARDS with ECMO & $45 \%$ & $39 \%(33-46)$ & 10.8 & 7.1 & 16.3 & 10.7 & 7.4 & 15.4 \\
\hline \multicolumn{9}{|l|}{ Virus } \\
\hline $\mathrm{A}\left(\mathrm{H}_{1} \mathrm{~N}_{1}\right)$ & $25 \%$ & $19 \%(18-21)$ & \multicolumn{3}{|c|}{ Ref } & \multicolumn{3}{|c|}{ Ref } \\
\hline $\mathrm{A}\left(\mathrm{H}_{3} \mathrm{~N}_{2}\right)$ & $19 \%$ & $16 \%(13-20)$ & 0.7 & 0.5 & 1.1 & 0.8 & 0.6 & 1.2 \\
\hline B & $17 \%$ & $16 \%(12-20)$ & 0.6 & 0.5 & 0.9 & 0.8 & 0.6 & 1.2 \\
\hline
\end{tabular}

ARDS; acute respiratory distress syndrome; CI: confidence intervals; ECMO: extracorporeal membrane oxygenation; OR: odds ratio; Ref: reference value.

Significant OR $(p<0.05)$ shown in grey.

Virus A was predominant among ICU cases in the four seasons studied, the proportion varying from $100 \%$ during the pandemic to $69 \%$ in $2012 / 13$. When compared with the distribution among influenza-confirmed GP patients, the virus $A\left(\mathrm{H}_{1} \mathrm{~N}_{1}\right)$ pdmog was always overrepresented among ICU cases, for instance, representing $40 \%$ of the influenza-confirmed GP patients and $85 \%$ of the influenza-confirmed ICU patients in $2010 / 11$ (Table 1).

ICU admission rate by age group described a U-shaped curve in 2011/12 and 2012/13 but not in 2009/10 and 2010/11. These two latter seasons were characterised by a large $\mathrm{A}\left(\mathrm{H}_{1} \mathrm{~N}_{1}\right)$ pdmog circulation and admission rates among the 15-64 year-old patients were equal or superior to the admission rate for those aged 65 years or older (Figure 2). Compared with other age groups, the highest rate was observed in patients under one year of age, except in 2011/12. Despite similar admission rates during the first three seasons, the proportion of $\geq 65$-year old patients among severe cases ranged from around $15 \%$ in $2009 / 10$ and $2010 / 11$ to
$50 \%$ in $2011 / 12$. In contrast, ICU admission rate for the elderly increased in 2012/13.

When compared with the age-group distribution of the general French population, children under the age of one year were over-represented among severe cases during all seasons studied. This group mainly included children under six months-old (the proportion varying from $69 \%$ in $2010 / 11$ to $63 \%$ in $2012 / 13$ ). In contrast, the 5-14 year-old group was always under-represented. Persons aged 15-64 years-old were over-represented in the $2009 / 10$ and $2010 / 11$ seasons and the 65 years-old and over group were over-represented in the two following seasons. The mean age of ICU cases increased significantly during the first three seasons and then declined in 2012/13 (Table 1).

The proportion of not-at-risk patients varied with the highest proportion reported in $2010 / 11$ (35\%). The proportions of pregnant women and obese patients with no other risk factors were high in $2009 / 10$ (3\%) and $2010 / 11$ (4\%). In 2011/12 and 2012/13, these values 
decreased to $1 \%$ for pregnant women in both years and $1 \%$ and $5 \%$ for obese patients, respectively (Table 1 ). The proportion of cases vaccinated with seasonal vaccine almost doubled (29\%) in 2011/12 compared with the two other seasons ( $13 \%$ in $2010 / 11$ and $16 \%$ in 2012/13).

The proportion of patients with ARDS was constant over time (ca 45\%), except during 2010/11 (64\%). The highest proportion of patients needing ECMO (10\%) or mechanical ventilation $(66 \%)$ was also observed in $2010 / 11$. The analysis was restricted to patients infected with $\mathrm{A}\left(\mathrm{H}_{1} \mathrm{~N}_{1}\right)$ pdmog in $2010 / 11$ and 2012/13, two seasons where at least $21 \%$ of the circulating virus was $A\left(\mathrm{H}_{1} \mathrm{~N}_{1}\right)$ pdmog (Table 1$)$. It showed significantly higher proportions of patients with ARDS $(68 \%$ and $57 \%$ respectively), ECMO ( $12 \%$ both seasons), or mechanical ventilation ( $70 \%$ and $69 \%$ respectively), compared with $2009 / 10$. The $p$ value was always less than 0.02 . The proportion of patients with a severity score of 2 was significantly lower in 2011/12 (3\%; 95\% $\mathrm{Cl}: 1-5)$ compared with the other seasons.

The case fatality ratio was not significantly different over time (Table 1). In the univariate analysis, it was significantly higher in patients for whom vaccination is usually recommended and patients infected with $\mathrm{A}\left(\mathrm{H}_{1} \mathrm{~N}_{1}\right)$ pdmog, and increased with age and severity (Table 2).

Factors associated with ARDS onset and death A significant relationship was observed between seasonal vaccination and ARDS presentation in the postpandemic period. Therefore, the multivariate analysis was restricted to this period (Table 3 ).

The risk factors independently associated with ARDS were as follows:

- Age between 36 and 55 years old (adjusted OR: 1.5; $95 \% \mathrm{Cl}: 1.2-2.0$ ), with age over 55 years-old as reference;

- Pregnancy with no other risk factor (adjusted OR: 3.0; $95 \% \mathrm{Cl}: 1.3-6.9)$ or obesity with no other risk factor (adjusted OR: 1.8; 95\% Cl: 1.1-3.0) with no risk factor as reference;

The protective factors independently associated with ARDS were as follows:

- Female sex (adjusted OR: 0.8; 95\% Cl: 0.7-0.98);

- Vaccination (adjusted OR: 0.7; (95\% Cl: 0.5-0.97);

- Infection with $\mathrm{A}\left(\mathrm{H}_{3} \mathrm{~N}_{2}\right)$ (adjusted OR: 0.5; $95 \% \mathrm{Cl}$ : $0.3-0.6$ ) or B strain (adjusted OR: $0.5 ; 95 \% \mathrm{Cl}$ : $0.4-0.6)$.

Since seasonal vaccination was not associated with death in multivariate analysis for the post-pandemic period (2010/11 to $2012 / 13$ ), we excluded this variable and integrated the $2009 / 10$ data in the final analysis (Table 2).

The risk factors independently associated with death were as follows:

- Severity score (score 1, adjusted OR: 4.2; 95\% Cl: 3.3-5.3; score 2, adjusted OR: 10.7; 95\% Cl: 7.4-15.4);

- Age > 55 years-old (adjusted OR: 1.5; 95\% Cl: 1.2-1.9).

The factors associated with a reduction in the risk of death were as follows:

- Patients for whom vaccination was not recommended (i.e. no chronic disease and age $<65$ years, adjusted OR: $0.5 ; 95 \% \mathrm{Cl}: 0.4-0.6)$, pregnancy with no other risk factor (adjusted OR: 0.3; 95\% Cl: 0.10.7 ) and obesity with no other risk factor (adjusted OR: $0.4 ; 95 \% \mathrm{Cl}: 0.3-0.7)$;

- Age $\leq 35$ years-old (adjusted OR: 0.7; 95\% Cl: $0.5-0.9)$.

There was no association between the virus type or subtypes and death. There was no interaction between age, severity score, risk factors and virus type.

\section{Discussion}

An influenza ICU surveillance system was set up in France during the 2009/10 pandemic and further developed with the active participation of ICU clinicians. In 2009, the accurate interpretation of ICU pandemic data was impossible since historical data were missing. In contrast, data obtained from the first four years of surveillance can serve as reference, showing seasonal variability in the characteristics of severe influenza cases.

The number of severe influenza cases admitted to ICUs dropped between the pandemic and the 2011/12 season and increased in $2012 / 13$, probably reflecting the unusual length of the 2012/13 influenza epidemic (13 weeks vs 8 or 9 weeks for the other seasons). However, comparisons over seasons should be made cautiously as the level of reporting may have varied over time. Completeness of the surveillance system was estimated in two regions by capture-recapture analysis: it was $90 \%$ during the pandemic in the Provence-Cote d'Azur region [10] and $80 \%$ in 2012/13 in the Pays-dela-Loire region [11]. There may be a tendency towards decreasing completeness over time but as surveillance remained active throughout the entire study period, with ICU wards being contacted regularly by their InVS regional office (Cire), we believe that this decline has remained limited.

Due to missing data regarding fatalities (13\% over the study period), vaccination status (30\% during the three years when information was collected) and influenza subtypes ( $23 \%$ of non-subtyped influenza A virus), 
Bivariate analysis of acute respiratory distress syndrome (ARDS) and multivariate analysis to identify risk factors associated with severe influenza-induced acute respiratory distress syndrome, France, influenza seasons 2010/11-2012/13

\begin{tabular}{|c|c|c|c|c|c|c|}
\hline & \multicolumn{2}{|c|}{ Univariate analysis } & \multicolumn{4}{|c|}{ Multivariate analysis } \\
\hline & \multirow[t]{2}{*}{ Complete cases } & \multirow{2}{*}{$\begin{array}{l}\text { Multiple imputation } \\
\qquad(95 \% \mathrm{Cl})\end{array}$} & \multicolumn{2}{|c|}{$\begin{array}{l}\text { Complete cases } \\
\quad(n=880)\end{array}$} & \multicolumn{2}{|c|}{$\begin{array}{l}\text { Multiple imputation } \\
\qquad(\mathrm{n}=1,839)\end{array}$} \\
\hline & & & OR & $95 \% \mathrm{Cl}$ & OR & $95 \% \mathrm{Cl}$ \\
\hline \multicolumn{7}{|l|}{ Age } \\
\hline $0-35$ years & $49 \%$ & $49 \%(44-54)$ & 0.8 & $0.5-1.3$ & 0.8 & $0.6-1.03$ \\
\hline $36-55$ years & $67 \%$ & $67 \%(63-71)$ & 1.4 & $0.9-2.0$ & 1.5 & $1.2-2.0$ \\
\hline$>55$ years & $50 \%$ & $49 \%(46-53)$ & \multicolumn{2}{|r|}{ Ref } & \multicolumn{2}{|c|}{ Ref } \\
\hline \multicolumn{7}{|l|}{ Sex } \\
\hline Male & $57 \%$ & $56 \%(53-60)$ & \multicolumn{2}{|r|}{ Ref } & \multicolumn{2}{|c|}{ Ref } \\
\hline Female & $51 \%$ & $51 \%(48-55)$ & 0.8 & $0.6-1.1$ & 0.8 & $0.7-0.98$ \\
\hline \multicolumn{7}{|l|}{ Risk factors } \\
\hline None & $57 \%$ & $57 \%(52-61)$ & \multicolumn{2}{|r|}{ Ref } & \multicolumn{2}{|c|}{ Ref } \\
\hline Chronic disease and age $\geq 65$ years & $51 \%$ & $51 \%(48-53)$ & 0.9 & $0.6-1.4$ & 0.9 & $0.7-1.1$ \\
\hline Pregnancy with no other risk factor & $78 \%$ & $78 \%(65-92)$ & 2.2 & $0.7-7.7$ & 3.0 & $1.3-6.9$ \\
\hline Obesity with no other risk factor & $75 \%$ & $75 \%(68-83)$ & 1.7 & $0.9-3.2$ & 1.8 & $1.1-3.0$ \\
\hline \multicolumn{7}{|l|}{ Seasonal vaccination } \\
\hline No & $55 \%$ & $57 \%(54-59)$ & \multicolumn{2}{|r|}{ Ref } & \multicolumn{2}{|c|}{ Ref } \\
\hline Yes & $42 \%$ & $43 \%(36-49)$ & 0.8 & $0.5-1.2$ & 0.7 & $0.5-0.97$ \\
\hline \multicolumn{7}{|l|}{ Virus } \\
\hline $\mathrm{A}\left(\mathrm{H}_{1} \mathrm{~N}_{1}\right)$ & $70 \%$ & $64 \%(61-67)$ & \multicolumn{2}{|c|}{ Ref } & \multicolumn{2}{|c|}{ Ref } \\
\hline $\mathrm{A}\left(\mathrm{H}_{3} \mathrm{~N}_{2}\right)$ & $44 \%$ & $39 \%(34-44)$ & 0.4 & $0.3-0.6$ & 0.5 & $0.3-0.6$ \\
\hline $\mathrm{B}$ & $44 \%$ & $44 \%(38-49)$ & 0.4 & $0.3-0.5$ & 0.5 & $0.4-0.6$ \\
\hline
\end{tabular}

ARDS: acute respiratory distress syndrome; $\mathrm{Cl}$ : confidence interval; OR: odds ratio; Ref: reference value.

Significant OR ( $p>0.05)$ shown in grey.

Data from the 2009/10 pandemic are excluded from this analysis.

we used a multiple imputation approach. No significant differences were observed between the complete case and multiple imputation analysis as shown in Table 2 and Table 3. Therefore, we are confident about the validity of the imputation procedure used and the results obtained. This process improved the power of the statistical analysis as more individuals participated in the multivariate analysis when the imputed data were used (for instance, 3,034 individuals vs 2,041 for risk factors for death study) and explained comparable OR in both approaches with larger confidence intervals in the complete case analysis. This resulted in statistically significant associations identified in the multiple imputation analysis but not in the complete case analysis.

Irrespective of the season, the $\mathrm{A}\left(\mathrm{H}_{1} \mathrm{~N}_{1}\right)$ pdmog virus was always over-represented among the severe cases in comparison to patients tested by GPs, reflecting its higher severity compared with $\mathrm{A}\left(\mathrm{H}_{3} \mathrm{~N}_{2}\right)$ or $B$ viruses. This was confirmed in the multivariate analysis, as infection with $A\left(\mathrm{H}_{1} \mathrm{~N}_{1}\right)$ pdmog was a risk factor for presenting an ARDS.

In 2010/11, the number of ICU cases has dropped but we observed a significantly higher proportion of ARDS patients compared with the pandemic (64\% vs $46 \%$ ), especially when analysis was restricted to patients infected with $\mathrm{A}\left(\mathrm{H}_{1} \mathrm{~N}_{1}\right)$ pdmog (68\% vs $\left.46 \%\right)$. Similarly, in $2012 / 13$, a significantly higher proportions of $\mathrm{A}\left(\mathrm{H}_{1} \mathrm{~N}_{1}\right)$ pdmog patients presented with ARDS (62\%) or needed ECMO (12\%) or mechanical ventilation (69\%) compared with $2009 / 10$. This finding is in favour of a persisting severity of influenza in the post-pandemic period, as observed in several countries [12-14]. It has also been observed in the past that more severe secondary waves of flu pandemics mostly involve adults with respiratory complications compared with the first wave, which mostly involve children $[15,16]$.

Whatever the season, the 5-14 year-old group was always under-represented among the ICU cases, even during the pandemic whereas serological studies showed that they were mostly infected [17]. The 15-64 year-old group was over-represented during the pandemic and the following year when $\mathrm{A}\left(\mathrm{H}_{1} \mathrm{~N}_{1}\right)$ pdmog was largely circulating, reflecting the higher risk of this group to develop a severe disease when infected with $\mathrm{A}\left(\mathrm{H}_{1} \mathrm{~N}_{1}\right)$ pdmo9. By contrast, this higher risk was observed for the elderly only when $A\left(\mathrm{H}_{3} \mathrm{~N}_{2}\right)$ and $B$ were the dominant virus.

When the virus $\mathrm{A}\left(\mathrm{H}_{1} \mathrm{~N}_{1}\right)$ pdmog circulated (during the 2009/10, 2010/11 and 2012/13 seasons), children 
under the age of one year had the highest ICU admission rate $(>4 / 100,000)$ compared with the other age groups. The ICU admission rate in this group was lower $(1.1 / 100,000)$ when the virus $\mathrm{A}\left(\mathrm{H}_{3} \mathrm{~N}_{2}\right)$ was dominant (season 2011/12). Most of the children under the age of one year $(65 \%)$ were aged less than six months. As infants can be protected through maternal antibody transfer during pregnancy, the high admission rate differences among the under one-year old children, with respect to the dominant virus subtype, could reflect the fact that their mothers were better protected against $\mathrm{A}\left(\mathrm{H}_{3} \mathrm{~N}_{2}\right)$ than they were against $\mathrm{A}\left(\mathrm{H}_{1} \mathrm{~N}_{1}\right)$ pdmog. These observations also confirmed that this young population is at risk of severe influenza, underlying the importance of implementing interventions to improve their protection, including vaccination of pregnant women and the rest of the household, social distancing, and prompt therapeutic management when symptoms occur.

Patients exhibiting the usual conditions for vaccination recommendation (i.e. $\geq 65$ years old or having chronic diseases) were at risk of death from influenza compared with the other patients. This vulnerability was expected and described before [18] and during the pandemics [19]. Our observation strengthens the need for better vaccination coverage among the targeted people, especially as, according to the French National Health Insurance data, vaccine coverage has declined from $60.2 \%$ in $2009 / 10$ to $50.1 \%$ in $2012 / 13$ [20]. It also strengthens the need for an early diagnosis and treatment of influenza-like illness in patients at risk for influenza complications. Similarly, as expected, the risk of dying increased with the severity score. In contrast, the association between the virus type and death was not significant, except for $B$ virus which had a protective factor in the complete cases analysis. This may be due to the adjustment on severity but also to the imputation process, possibly resulting in few misclassifications of true $\mathrm{A}\left(\mathrm{H}_{3} \mathrm{~N}_{2}\right)$ cases as $\mathrm{A}\left(\mathrm{H}_{1} \mathrm{~N}_{1}\right)$ pdmog cases.

In the seasons 2010/11, 2011/12 and 2012/13, $\mathrm{A}\left(\mathrm{H}_{1} \mathrm{~N}_{1}\right)$ pdmog was associated with ARDS. Increased incidence of ARDS due to viral pneumonia has been consistently reported during many pandemics [21]. Our finding confirms that $A\left(\mathrm{H}_{1} \mathrm{~N}_{1}\right)$ pdmog is still a risk factor for ARDS, even after the $2009 / 10$ wave. As described for mortality [15], increasing ARDS risk may persist for 3 to 10 years and should be taken into account when $\mathrm{A}\left(\mathrm{H}_{1} \mathrm{~N}_{1}\right)$ pdmog will be circulating in the following years. This risk is possibly due to the lack of immunity in the population. This hypothesis seems coherent with the protective effect of the vaccination against ARDS. However, as the data showed an association between ARDS and death, an association between vaccination and death in the post-pandemic period was expected which was not the case: vaccinated ICU patients did not seem to be better protected against death (adjusted OR: 0.9 (o.6-1.4)), even after adjusting on age and risk factors. This could be due to a lack of power of our study (216 deaths) as positive vaccination impact on mortality has regularly been described in the literature [22-24].

With 800,000 births per year in France, pregnant women are estimated to account for a slightly under $2 \%$ of the mainland population. Therefore, pregnant women with and without chronic diseases were overrepresented in 2009/10 (5\%) and 2010/11 (4\%) among ICU cases. Estimated to represent $15 \%$ of French adults over 17 years-old in 2012 [25], obese persons (with and without associated chronic diseases) were also overrepresented during the pandemic and the subsequent season (23\%). The over-representation of those two groups is probably linked to the $\mathrm{A}\left(\mathrm{H}_{1} \mathrm{~N}_{1}\right)$ pdmog virus circulation during these two seasons (almost 100\% and $50 \%$ respectively of the influenza-confirmed GP patients). The higher risk of severe influenza in pregnant women has been well documented during pandemics since 1918 [26] and this risk for patients with obesity was highlighted during the 2009/10 pandemic [26-28]. The over-representation of each group disappeared in 2011/12 and 2012/13, two seasons with low contribution of $\mathrm{A}\left(\mathrm{H}_{1} \mathrm{~N}_{1}\right)$ pdmog ( $(25 \%)$. However, among ICU cases, both pregnant women and obese patients with no other risk factor had a higher risk of developing ARDS than the other patients, even after adjusting for age and virus type or subtype. This finding supports the French vaccine recommendations which included those two groups in the influenza vaccine target in 2012.

When not associated with chronic diseases, neither pregnancy nor obesity appeared as risk factors associated with death. In the literature, increased influenzarelated fatalities in pregnancy [29] and obesity [26] have regularly been observed, but this is not the case with our results. This may be explained by different choices for the reference population to estimate the risk: in the literature the reference population used was mainly the general population, whereas in our study we used patients aged 65 years old and older or with chronic diseases.

Our data regarding risk factors for death and ARDS should be interpreted with caution, as the number of variables to adjust the model was limited. In particular, we were not able to collect data on the use of antiviral therapy, which probably interferes with the estimates of the risk for severe disease and death.

In conclusion, these first four years of surveillance confirm that influenza disease may be severe. Risks for ICU admission, ARDS onset, mechanical ventilation and ECMO requirement are still higher for patients infected with $A\left(\mathrm{H}_{1} \mathrm{~N}_{1}\right)$ pdmog, even three years after the pandemic. Irrespective of the virus strain, children under one year-old are at risk for ICU admission. A higher risk was observed for adults when $\mathrm{A}\left(\mathrm{H}_{1} \mathrm{~N}_{1}\right)$ pdmog was circulating, and for the elderly when it was not. Vaccination seems to be protective against the onset of influenza-induced ARDS. All our data support the 
importance of ICU surveillance in determining groups at risk of developing severe influenza disease and its potential for providing early warning of atypical severe patterns.

\section{Acknowledgements}

We thank all the clinicians who were involved in the surveillance and all the laboratories who contributed to the RT-PCR results. We also thank all colleagues from the regional units of the InVS (Cires), and Etienne Lucas for data management.

\section{Conflict of interest}

None declared.

\section{Authors' contributions}

Isabelle Bonmarin, Emmanuel Belchior and Daniel LevyBruhl were mainly responsible for the design and supervision of the surveillance. Jean Bergounioux, Christian Brun-Buisson, Bruno Mégarbane, Jean Loup Chappert and Bruno Hubert were mainly involved in the data collection. Isabelle Bonmarin, Yann Le Strat and Daniel Levy-Bruhl were in charge of the data analysis. Isabelle Bonmarin drafted the paper and all the authors revised it.

\section{References}

1. Réseau des Groupes Régionaux d'Observation de la Grippe (GROG). [Accessed 31 Jul 2014]. Available from: http://www. grog.org/

2. Réseau Sentinelles. Paris: Institut national de la santé et de la recherche médicale (INSERM), Université Pierre et Marie Curie (UPMC). [Accessed 31 Jul 2014]. Available from: http://www. sentiweb.org/

3. Fuhrman C, Bonmarin I, Bitar D, Cardoso T, Duport N, Herida $M$, et al. Adult intensive-care patients with 2009 pandemic influenza $A\left(\mathrm{H}_{1} \mathrm{~N}_{1}\right)$ infection. Epidemiol Infect. 2011;139(8):12029. Available from: DOI: $10.1017 /$ So950268810002414 PMID: 20974021

4. Health Protection Agency (HPA). HPA Weekly National Influenza Report - Summary of UK surveillance of influenza and other seasonal respiratory illnesses - Week 49/2010. 9 Dec 2010. [Accessed 9 Dec 2014]. London: HPA. Available from: http:// www.hpa.org.uk/webc/HPAwebFile/HPAweb_C/1287146267647

5. van lerssel $S H$, Leven $M$, Jorens $P G$. Severe influenza $A\left(H_{1} N_{1}\right)_{2009}$ infection: a single centre experience and review of the literature.Acta Clin Belg. 2012;67(1):1-6.PMID: 22480031

6. Webb SA, Pettilä V, Seppelt I, Bellomo R, Bailey M, Cooper DJ, et al. Critical care services and $2009 \mathrm{H}_{1} \mathrm{~N}_{1}$ influenza in Australia and New Zealand. N Engl J Med. 2009;361(20):192534. Available from: DOI: 10.1056/NEJMoao908481 PMID: 19815860

7. Helferty M, Vachon J, Tarasuk J, Rodin R, Spika J, Pelletier L. Incidence of hospital admissions and severe outcomes during the first and second waves of pandemic ( $\left.\mathrm{H}_{1} \mathrm{~N}_{1}\right)$ 2009.CMAJ. 2010;182(18):1981-7. Available from: DOI: 10.1503/cmaj.100746 PMID: 21059773

8. Ministère des affaires sociales et de la Santé. Calendrier des vaccinations et recommandations vaccinales 2014. [Schedule of vaccinations and vaccine recommendations in 2014]. Paris: Ministère des affaires sociales et de la Santé; 15 May 2014. French. Available from: http://www.sante.gouv.fr/calendriervaccinal.html

9. Costagliola D, Flahault A, Galinec D, Garnerin P, Menares J, Valleron AJ. A routine tool for detection and assessment of epidemics of influenza-like syndromes in France.Am J Public Health. 1991;81(1):97-9. Available from: DOI: 10.2105/ AJPH.81.1.97 PMID: 1983924

10. El Farouki K, Mantey K, Lasalle JL, Fuhrman C, Chiron E, Malfait P. Exhaustivité des signalements de cas graves de grippe $A\left(\mathrm{H}_{1} \mathrm{~N}_{1}\right) 2009$ en Provence-Alpes-Côte d'Azur et Corse, France, 2009-2010.Rev Epidemiol Sante Publique. 2010;58(Suppl 2):S64. Available from: DOI: 10.1016/j.respe.2010.06.058
11. Hubert B. Epidémie de grippe dans les Pays de la Loire. Saison 2012-2013. [Influenza outbreak in the Loire Valley. 2012-2013 season]. Bulletin de veille sanitaire - Cire Pays de la Loire 2013 Dec $1 ;(19): 4-5$. Available from: www.invs.sante.fr/content/ download/81677/298216/version/19/file/bvs_pays_de loire_19_2013.pdf

12. Green HK, Ellis J, Galiano M, Watson JM, Pebody RG. Critical care surveillance: insights into the impact of the 2010/11 influenza season relative to the $2009 / 10$ pandemic season in England.Euro Surveill. 2013;18(23).PMID: 23787130

13. Delgado-Rodríguez M, Castilla J, Godoy P, Martín V, Soldevila $\mathrm{N}$, Alonso J, et al. Different prognosis in hospitalized patients with influenza one season after the pandemic $\mathrm{H}_{1} \mathrm{~N}_{1}$ influenza of 2009-2010 in Spain. Influenza Other Respi Viruses. 2013;7(6):1336-42. Available from: DOI: 10.1111/irv.12119 PMID: 23647645

14. Gubbels S, Krause TG, Bragstad K, Perner A, Mølbak K, Glismann S. Burden and characteristics of influenza $A$ and $B$ in Danish intensive care units during the 2009/10 and 2010/11 influenza seasons.Epidemiol Infect. 2013;141(4):76775. Available from: DOI: 10.1017/So950268812001471 PMID: 22793496

15. Saglanmak N, Andreasen V, Simonsen L, Mølbak K, Miller MA, Viboud C. Gradual changes in the age distribution of excess deaths in the years following the 1918 influenza pandemic in Copenhagen: using epidemiological evidence to detect antigenic drift.Vaccine. 2011;29(Suppl 2):B42-8. Available from: DOI: 10.1016/j.vaccine.2011.02.065 PMID: 21757103

16. Bansal S, Pourbohloul B, Hupert N, Grenfell B, Meyers LA. The shifting demographic landscape of pandemic influenza.PLoS ONE. 2010;5(2):e9360. Available from: DOI: 10.1371/journal. pone.0009360 PMID: 20195468

17. H1N1pdm serology working group,Van Kerkhove MD, Hirve S, Koukounari A, Mounts AW, . Estimating age-specific cumulative incidence for the 2009 influenza pandemic: a meta-analysis of $\mathrm{A}\left(\mathrm{H}_{1} \mathrm{~N}_{1}\right)$ pdmog serological studies from 19 countries. Influenza Other Respi Viruses. 2013;7(5):872-86. Available from: DOI: 10.1111/irv.12074

18. Quandelacy TM, Viboud C, Charu V, Lipsitch M, Goldstein E. Age- and sex-related risk factors for influenza-associated mortality in the United States between 1997-2007.Am J Epidemiol. 2014;179(2):156-67. Available from: DOI: 10.1093/ aje/kwt235 PMID: 24190951

19. Louie JK, Jean C, Acosta M, Samuel MC, Matyas BT, Schechter $\mathrm{R}$. A review of adult mortality due to 2009 pandemic $\left(\mathrm{H}_{1} \mathrm{~N}_{1}\right)$ influenza A in California.PLoS ONE. 2011;6(4):e18221. Available from: DOI: 10.1371/journal.pone.0018221 PMID: 21483677

20. Institut de Veille Sanitaire (InVS). Couverture vaccinale. Grippe. Groupe d'âge. [Vaccine coverage. Influenza. Age groups]. [Accessed 27 Aug 2015]. French. Available from: http://www. invs.sante.fr/Dossiers-thematiques/Maladies-infectieuses/ Maladies-a-prevention-vaccinale/Couverture-vaccinale/ Donnees/Grippe

21. Gachot B, Vachon F. (Severe "malignant" influenza in the light of past history). La grippe maligne vue à la lumière du passé.Med Mal Infect. 2010;40(2):55-9.DOI: 10.1016/j. medmal.2009.12.001 PMID: 20080371

22. Chan TC, Fan-Ngai Hung I, Ka-Hay Luk J, Chu LW, HonWai Chan F. Effectiveness of influenza vaccination in institutionalized older adults: a systematic review.J Am Med Dir Assoc. 2014;15(3):226.e1-6. Available from: DOI: 10.1016/j. jamda.2013.10.008 PMID: 24321878

23. Ridenhour BJ, Campitelli MA, Kwong JC, Rosella LC, Armstrong $B G$, Mangtani P, et al. Effectiveness of inactivated influenza vaccines in preventing influenza-associated deaths and hospitalizations among Ontario residents aged $\geq 65$ years: estimates with generalized linear models accounting for healthy vaccinee effects. PLoS ONE. 2013;8(10):e76318. Available from: DOI: 10.1371/journal.pone.0076318 PMID: 24146855

24. Fireman B, Lee J, Lewis N, Bembom O, van der Laan M, Baxter R. Influenza vaccination and mortality: differentiating vaccine effects from bias.Am J Epidemiol. 2009;170(5):650-6. Available from: DOI: 10.1093/aje/kwp173 PMID: 19625341

25. INSERM/KANTAR HEALTH/ROCHE. Enquete nationale épidémiologique sur le surpoids et l'obésité - 2012. [National epidemiological survey on overweight and obesity]. [Accessed 20 Nov 2013]. French. Available from: http://www.roche.fr/ content/dam/corporate/roche_fr/doc/obepi_2012.pdf

26. Karlsson EA, Marcelin G, Webby RJ, Schultz-Cherry S. Review on the impact of pregnancy and obesity on influenza virus infection. Influenza Other Respi Viruses. 2012;6(6):449-60. Available from: DOI: 10.1111/j.1750-2659.2012.00342.x PMID: 22335790

27. Fezeu L, Julia C, Henegar A, Bitu J, Hu FB, Grobbee DE, et al. Obesity is associated with higher risk of intensive care unit admission and death in influenza $A\left(\mathrm{H}_{1} \mathrm{~N}_{1}\right)$ 
patients: a systematic review and meta-analysis. Obes

Rev. 2011;12(8):653-9. Available from: DOI: 10.1111/j.1467-

789X.2011.00864.x PMID: 21457180

28. Kok J, Blyth CC, Foo H, Bailey MJ, Pilcher DV, Webb SA, et

al. Viral pneumonitis is increased in obese patients during the first wave of pandemic $A\left(\mathrm{H}_{1} \mathrm{~N}_{1}\right) 2009$ virus. PLoS ONE. 2013;8(2):e55631. Available from: DOI: 10.1371/journal. pone.0055631 PMID: 23418448

29. Skowronski DM, De Serres G. Is routine influenza immunization warranted in early pregnancy?Vaccine. 2009;27(35):4754-70. Available from: DOI: 10.1016/j.vaccine.2009.03.079 PMID:

19515466 